\title{
VALIDATION OF A NEW CLINICAL SIGN OF LUMBAR FACET SYNDROME
}

\author{
VALIDAÇÃO DE UM NOVO SINAL CLIINICO DA SÍNDROME DA FACETÁRIA LOMBAR \\ VALIDACIÓN DE UN NUEVO SIGNO CLÍNICO DEL SÍNDROME FACETARIO LUMBAR \\ Juan Carlos Acevedo Gonzalez \\ 1. Pontificia Universidad Javeriana, Hospital Universitario San Ignacio, Department of Neuroscience, Neurosurgery Unit, Bogota, Colombia.
}

\begin{abstract}
Objective: Facet joints are true synovial joints, which derive their nerve supply from the sinuvertebral or recurrent nerve of Luschka as well as the posterior primary division of the corresponding spinal nerve. Diagnosis of low-back pain originating in the facet joints is difficult, and has traditionally relied upon invasive tests. To aid in the clinical diagnosis of this condition, the senior author described a new clinical sign. The following research project was designed to test the utility of this sign in the diagnosis of lumbar facet joint pain. Methods: We conducted a prospective evaluation of patients suspected of having low back pain secondary to facet joint involvement (Lumbar Facet joint Pain Syndrome - LFPS) during a twelve month observation period; candidate patients were evaluated clinically using the new diagnostic sign, which was then compared to findings on radionuclide bone scans and diagnostic medial branch blocks. Contingency table analysis was performed to calculate the sensitivity, specificity, positive and negative predictive values and accuracy of the new clinical sign. Results: Contingency table analysis showed the following operating characteristics for the new diagnostic sign: Sensitivity: $70.37 \%$, Specificity: $50 \%$, Positive predictive value: $90.47 \%$, Negative predictive value: $20 \%$ and accuracy $67.7 \%$. Conclusions: Although the new clinical sign failed to show the same operating characteristics as the ones originally described, it has high sensitivity coupled with a good positive predictive value. We consider that although the sign by itself is not diagnostic of lumbar facet joint pain, its presence should alert the clinician to the diagnosis and the possibility of requiring additional testing. Level of Evidence III; Case control studyg.
\end{abstract}

Keywords: Pain; Back pain; Zygapophyseal joint; Diagnosis; Low back pain.

\section{RESUMO}

Objetivo: Articulações facetárias são verdadeiras articulações sinoviais, que inervação do Nervo sinuvertebral ou recorrente de Luschka, bem como a divisão principal posterior do nervo espinhal correspondente. O diagnóstico da dor lombar originário de articulações é difícil e tem tradicionalmente testes invasivos. Para auxiliar no diagnóstico clínico desta condição, o autor descreveu um novo sinal clínico. 0 seguinte projeto de pesquisa foi projetado para testar a utilidade do sinal descrito no diagnóstico da dor na articulação faceta lombar. Métodos: Foi realizada uma avaliação prospectiva de pacientes com suspeita de dor lombar secundária a faceta participação conjunta (Lombar Facet síndrome da articulação Dor - LFPS) durante um período de observação de 12 meses; pacientes candidatos foram avaliados clinicamente usando o novo sinal diagnóstico, comparados com as conclusões sobre cintilografia óssea de radionuclídeos e blocos de ramo medial diagnóstico. Análise de tabela de contingência foi realizada para calcular a sensibilidade, especificidade, valores preditivos positivos e negativos e precisão do novo sinal clínico. Resultados: análise de tabela de contingência mostrou as seguintes características de funcionamento do novo sinal de diagnóstico: sensibilidade: 70,37\%, especificidade: 50\%, valor preditivo positivo: 90,47\%, valor preditivo negativo: $20 \%$ e precisão de 67,7\%. Conclusões: Apesar do novo sinal clínico não conseguir mostrar as mesmas características de operação como as inicialmente descritas, que tem uma sensibilidade elevada acoplada com um bom valor preditivo positivo, consideramos que, embora o sinal por si só - t diagnóstico da dor nas articulações faceta lombar - sua presença deve alertar o clínico do diagnóstico e a possibilidade de exigir testes adicionais. Nível de Evidência III; Estudo de caso-controleg.

Descritores: Dor, Dor nas costas, Articulação zigapofisária, diagnóstico, Dor lombar

\section{RESUMEN}

Objetivo: Las articulaciones facetarias son verdaderas articulaciones sinoviales inervadas por el nervio sinuvertebral o recurrente de Luschka y por la división principal posterior del nervio espinal correspondiente. El diagnóstico del dolor lumbar originario de esas articulaciones es difícil y tradicionalmente las pruebas son invasivas. Para ayudar en el diagnóstico clínico de esta condición, el autor describió un nuevo signo clínico. El siguiente proyecto de investigación fue diseñado para probar la utilidad del signo descrito en el diagnóstico del dolor en las articulaciones facetarias lumbares. Métodos: Se realizó una evaluación prospectiva de pacientes con sospecha de dolor lumbar por inflamación de la articulación facetaria (síndrome facetario lumbar, SFL) durante un período de observación de 12 meses. Los pacientes candidatos fueron evaluados clínicamente usando el nuevo signo diagnóstico, que se comparó con las conclusiones de la gammagrafía ósea y los bloqueos de la rama medial. El análisis de tabla de contingencia se realizó para calcular sensibilidad, especificidad, valores predictivos positivos y negativos y precisión del nuevo signo clínico. Resultados: El análisis de tabla de contingencia mostró las siguientes características de desempeño del nuevo signo diagnóstico: sensibilidad de 70,37\%; especificidad de 50\%; valor

Study conducted at the Neurosurgery Unit, Department of Neuroscience, Hospital Universitario San Ignacio, Pontificia Universidad Javeriana.

Correspondence: Juan Carlos Acevedo-Gonzalez. Hospital Universitario San Ignacio / Pontificia Universidad Javeriana, Departamento de Neurociencias. Carrera 7 № 40-62, Bogotá - Colombia. jacevedog@gmail.com 
predictivo positivo de 90,47\%; valor predictivo negativo de $20 \%$ y precisión de $67,7 \%$. Conclusiones: A pesar de que el nuevo signo clínico no pudo mostrar las mismas características de desempeño descritas inicialmente, tiene una sensibilidad elevada acoplada con un buen valor predictivo positivo. Consideramos que, aunque el signo por sí solo no es diagnóstico de dolor en las articulaciones facetarias lumbares, su presencia debe alertar al clínico sobre el diagnóstico y la posibilidad de exigir pruebas adicionales. Nivel de Evidencia III, Estudio de caso-control's.

Descriptores: Dolor; Dolor de espalda; Articulación cigapofisaria; Diagnóstico; Dolor de la región lumbar.

\section{INTRODUCTION}

Low back pain (LBP) is a pathological entity of varied causes. It can present as an isolated symptom or in combination with others. It is one of the most frequent causes of consultation in the emergency room, accounting for $2 \%$ to $5 \%$ of all doctor visits annually. ${ }^{1}$ It is estimated that approximately two thirds of the population will present with an episode of low back pain during their lifetime, and that up to $85 \%$ of the American population suffers from at least one episode of low back pain per year. ${ }^{2,3}$ Most cases improve significantly in less than four weeks, with only a small proportion becoming chronic, with limitations on their daily activities. ${ }^{3}$ The anatomical structures that can cause back pain are multiple ${ }^{4}$ and include the periosteum, spinal roots, blood vessels, ligaments, muscles, tendons, dorsal root ganglion, annulus fibrosus, meninges, sacroiliac joints, and facet joints. Thus, in the differential diagnosis of low back pain, we must consider different etiologies such as: lumbar stenosis, spondylolisthesis, ankylosing spondylitis, facet joint pain, referred pain, cancer pain and infections such as osteomyelitis or discitis. ${ }^{5}$

In 1911, Goldwaith recognized the importance of the facet joints as potential causes of low-back pain. He particularly emphasized the fact that asymmetric facet joint hypertrophy could cause nerve compression. In 1927, an Italian surgeon by the name of Putti published a work detailing how degenerative changes of the facet joints were a cause of low-back pain. In 1937, Ghormley used the term "facet syndrome" for the first time. At the time, Mixter and Barr's monograph on disc herniation and low-back pain shadowed his work. It was not until 1941, when Badgley reiterated the fact that not every patient with LBP had a herniated disc, that attention shifted to the different spinal structures as causes of pain. In 1963, Hirsch demonstrated that LBP could be reproduced in some patients by injecting hypertonic saline solution into the facet joints. Mooney, Robertson and McCall reproduced those findings during the seventies using fluoroscopic guidance to inject hypertonic solutions into the facet joints. ${ }^{6}$ Other authors have demonstrated the pathological changes that these joints are subjected to over time, ${ }^{7-9}$ and the inflammatory changes associated with them. ${ }^{10-12}$

Taking all this information into account, we believe that facet syndrome is a separate nosological entity with characteristic symptoms, methods of diagnosis and treatment. ${ }^{13,14}$ We prefer to use the term lumbar facet joint pain syndrome (LFPS), and propose the following definition:

Lumbar facet joint pain syndrome is a clinical entity characterized by acute or chronic low back pain. The pain can occasionally radiate to the lower extremities but never in a dermatomal pattern. It is worsened mainly by extension and rotational movements of the spine and is originated by inflammatory or degenerative changes of the lumbar facet (zygapophyseal) joints.

Clinically, LFPS is characterized by the presence of low back pain, which is predominantly axial. It can radiate to the lower extremities, especially the buttocks, backs of the thighs, sacroiliac region, paravertebral lumbar musculature hip (greater trochanter) and inguinal crease. Nonetheless, there is never a dermatomal distribution of the pain; the pain is somatic in nature, and almost never extends below the knees. The pain is worst with extension and rotation movements. Patients will manifest increased pain when changing from the seating to the standing positions. ${ }^{6}$

One of the characteristics of LFPS is the lack of consistent information regarding its true incidence and prevalence. ${ }^{15}$ Reported rates of prevalence vary between $5 \%$ and $95 \%$. Some have even questioned the fact that facet joints can be solely responsible for causing LBP. ${ }^{16}$ This is largely due to the wide variability between diagnostic methods, and the lack of statistical power of these methods; in other words, there is no true gold standard for the diagnosis of LFPS.

The clinical diagnosis of LFPS remains a challenge, even for the most experienced clinicians. This is largely due to the fact that the facet joints share a common innervation with other spinal structures. ${ }^{17}$ The clinical diagnosis of LFPS relies not only on a good history and physical examination, but also on additional studies such as radionuclide bone scans ${ }^{18}$ and medial branch blocks (MBBs), which have been suggested as useful diagnostic tools. ${ }^{19,20} \mathrm{MRI}$ is also an adequate diagnostic method that allows the structural deterioration of the joint to be visualized.

Nonetheless, there is still a lack of clinical signs designed to isolate the lumbar facet joints for the purpose of reproducing pain originating from the joints. The clinical evaluation of patients with suspected LFPS is based on non-specific tests, such as paravertebral muscle palpation and the induction of forced extension and rotation movements. With the purpose of addressing this lack of methods for the clinical diagnosis of LFPS, the senior corresponding author (JCA) proposed in 2004 a new clinical sign (Figure 1), which was preliminarily tested in four different groups of patients: ${ }^{21}$

1. Patients with LBP and associated radiculopathy secondary to lumbar spinal stenosis or disc herniation.

2. Patients with low back pain without radiculopathy but with different etiologies than LFPS (myofascial syndromes, sacroiliac joint pain, hip bursitis, etc.).

3. Patients with clinical evidence of LFPS confirmed with radionuclide bone scans.

4. A control group of patients without LBP.

The initial study reported the following operating characteristics for the sign:

- Sensitivity: $95 \%$

- Specificity: $96 \%$

- Positive Predictive Value: $90 \%$

- Negative Predictive Value: $98 \%$

Taking into account these very promising results, we set out to design a new study to validate the initial results by analyzing its performance in a single group of patients with LFPS confirmed by medial branch blocks.

\section{METHODS}

After obtaining approval from the Institutional Review Board (IRB), we conducted a prospective evaluation of patients with suspected LFPS, through our neurosurgery outpatient clinic, over a twelve-month observation period. We included patients older than 18 years with chronic (longer than three months in duration) low-back pain who had a positive radionuclide bone scan (radiotracer uptake in the lumbar facet joints in the absence of uptake in other regions of the spine such as the SIJ, discs or spinous processes). We chose patients without a previous history of medial branch blocks, or who had medial branch blocks performed earlier with at least an $80 \%$ reduction in pain on the visual analog scale. We excluded patients with a previous history of surgery for the treatment of LBP, patients with known or suspected malignancies of the spine, any patient with suspected LBP from causes other than LFPS, patients with negative 


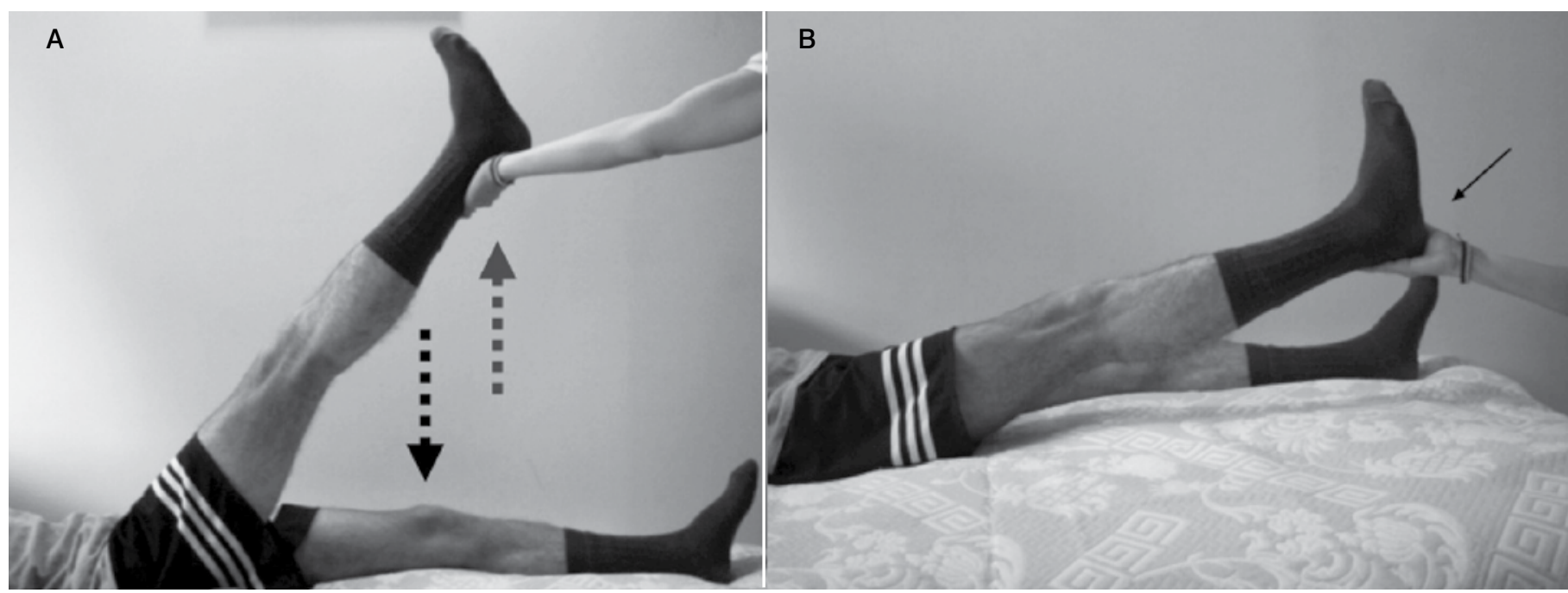

Figure 1. Clinical assessment of the new sign: the patient is in the supine position. We ask the patient to lift up one leg fully extended. He or she is asked to bring the leg back down against the resistance of the evaluator, who holds the patient leg at the ankle (A). The examiner then suddenly releases the pressure on the patient's leg, but before it touches the examination table, the examiner quickly holds it again (B), stopping the patient's leg from abruptly hitting the surface of the table. The sign is considered positive if pain is reproduced on the same side as the symptoms from the suspected facet joints.

bone scans, and patients with known LFPS associated with other pathologies, such as trauma, disc herniation, pathological fractures, or SIJ pain (Table 1).

For a suspected diagnosis of LFPS, we considered the history of chronic axial LBP, occasionally radiated to the lower extremities, gluteal or paraspinous regions without dermatomal patterns of distribution, in patients who complained of worsening pain when sitting up, or whose symptoms were reproduced with extension and rotation of the spine. We explored the new clinical sign in all these patients, who were then screened with a radionuclide bone scan that was only considered positive when there was clear facet joint radiotracer uptake without significant uptake in any other spinal structures in the lumbosacral region. We evaluated other sources of imaging like CT and MRI of the spine but did not include results from those tests as indicators of LFPS.

Patients with a positive history, physical exam and radionuclide bone scan were then electively scheduled for a medial branch block of the compromised facet joints. The procedure was performed under local anesthesia with fluoroscopic guidance. The patients were always positioned prone. Sterile prepping of the skin was done with chlorhexidine gluconate solution. A small dose of $1 \%$ lidocaine

Table 1. Selection criteria

\begin{tabular}{c}
\hline Inclusion criteria \\
\hline Age $>18$ years \\
\hline Chronic low-back pain (more than three months in duration) \\
\hline Clinical suspicion of Lumbar Facet joint Pain Syndrome \\
\hline Positive bone scan with lumbar facet joint tracer uptake \\
\hline Patients without a previous history of facet joint injections or \\
\hline in previous facet joint injection with more than 80\% improvement \\
\hline Previous surgery to treat low-back pain \\
\hline Patients with known or suspected malignancies of the spine \\
\hline Suspected low-back pain of a different etiology than facet joint pain \\
\hline Negative bone scan
\end{tabular}

without epinephrine was injected subdermally into each of the corresponding levels to be treated. Using a 25G spinal needle directed to the junction of the superior facet - transverse process junction, a medial branch block was performed with a mix of $1 \%$ lidocaine without epinephrine and dexamethasone (Total volume per joint level: $2.5 \mathrm{ml}$ ). No medication was injected directly into the facet joints. Only joints with positive radiotracer uptake were treated. The facet level in which the treatment was performed corresponded to the level affected in the positive radionuclide bone scan.

Patients were discharged the same day without any pain medication, except for Acetaminophen PRN; the same surgeon performed all the procedures (JCA). Patients were then re-evaluated one week after their initial procedure in the outpatient clinic to evaluate their clinical response according to the visual analog scale. An $80 \%$ reduction in pain after the procedure was considered a positive response to the treatment.

Prior to the data collection, an evaluation sheet was created to screen for candidate patients. The sheet contained basic demographic information, including name, age, medical record number and sex, as well as information necessary to screen potential candidate patients, such as previous history of MBBs. The sheet also contained a $2 \times 2$ table to record the patient's response after evaluation of the new clinical sign on each side.

All of the information was recorded in a computerized spreadsheet (Microsoft Office Excel $\AA^{\circledR 2010}$ ) for subsequent contingency table analysis using the response to MBBs as the gold standard. The following formulas were used for the calculation of the operating characteristics of the new clinical sign after creating a standard $2 x$ 2 table (Table 2). The work was approved by the Ethics Committee.

Informed consent was dispensed with because the planned treatment was not modified, and determining the presence or absence of the sign did not involve any invasive method.

Table 2. Clinical results.

\begin{tabular}{l|c|c|c|c}
\hline \multirow{2}{*}{$\begin{array}{c}\text { New lumbar facet joint } \\
\text { pain clinical sign }\end{array}$} & \multicolumn{4}{|c}{ Medial branch blocks } \\
\cline { 2 - 5 } & & Positive & Negative & Total \\
\cline { 2 - 5 } & Positive & 19 & 2 & 21 \\
\cline { 2 - 5 } & Negative & 8 & 2 & 10 \\
\hline & Total & 27 & 4 & 31 \\
\hline
\end{tabular}




\section{RESULTS}

A total of 31 patients were recruited, 15 male (48\%) and 16 female (52\%). The average age was 60 years (range $41-83)$. Twenty-one patients (68\%) had a positive sign. Of the total number of patients, 19 had both a positive sign and diagnostic MBB. Eight patients had a negative clinical sign with a positive response to an MBB. Two patients had a positive sign with a negative MBB and 2 patients had both a negative sign and an MBB. Contingency table analysis (Table 2) showed the following operating characteristics for the new diagnostic sign:

- Sensitivity: $70.37 \%$

- Specificity: $50 \%$

- Positive predictive value: $90.47 \%$

- Negative predictive value: $20 \%$

- Accuracy: $67.7 \%$

Eighty-seven percent of patients $(n=27)$ had a positive MBB (greater than $80 \%$ reduction in pain), and all patients had at least a $50 \%$ reduction of pain for at least 72 hours. There were no postoperative complications recorded after any of the procedures. Of the 27 patients who had a positive MBB, 19 (70\%) had a positive sign.

\section{DISCUSSION}

The facet joints are composed of the superior joint facet of the inferior vertebra and the inferior joint facet of the superior vertebra. It is a true synovial joint capable of storing up to $1.5 \mathrm{~mL}$ of fluid, composed of hyaline articular cartilage, synovial membrane and a fibrous joint capsule. Facet joints (also called zygapophyseal joints) have different degrees of orientation in the sagittal and coronal planes, ${ }^{22-24}$ this characteristic gives them variable biomechanical properties, depending on the spinal level. In the lumbar spine, the articular facet originates at the junction of the pedicle and lamina. The superior facet is orientated dorsally and medially and its surface is concave, which allows it to articulate with the inferior articular facet of the superior vertebra, which has a convex surface and is oriented ventrally and laterally.

The medial rami of the corresponding segmental arteries have branches that help irrigate the inner portion of the spinal canal, lamina, spinous processes, paraspinal muscles and joint facets. Venous drainage follows the same pattern, after which blood drains into the perivertebral venous plexus within the spinal canal.

The recurrent nerve of Luschka (or sinuvertebral nerve) ${ }^{25}$ originates from the ventral spinal nerve and from fibers of the grey rami communicans. It returns towards the spinal canal, passing underneath the mammilo, an accessory ligament, after which it divides into an ascending and a descending branch. These branches will innervate not only the articular facets, but also the external portion of the annulus fibrosus, ligaments, blood vessels and dura mater. The terminal branches anastomose with those of upper and lower levels.

As mentioned previously, from the beginning of the $20^{\text {th }}$ century, physicians have recognized the importance of facet joints as originators of pain in the lower back. The non-specific innervation of facet joints makes it difficult for patients to describe the pain and for clinicians to isolate the symptoms during physical examination. To the best of our knowledge, there are no real clinical signs specifically designed to assess the facet joint. With this in mind, Acevedo described a clinical sign, which is thought to provoke the lumbar facet joints by suddenly distracting the articular surfaces. In its initial description, the sign had excellent diagnostic reliability with calculated sensitivity and specificity of $95 \%$ and $96 \%$, respectively. ${ }^{21}$ Nonetheless, the sign was evaluated in a heterogeneous group of patients with varied sample sizes, which limits generalizations to a larger population. Taking this into account, we designed a newer study with the purpose of evaluating the performance of the sign in a population of patients with LFPS, and calculating its operating values using diagnostic medial branch blocks as the gold standard.

Although sensitivity is high (70.3\%) it is lower than that reported with the first description of the sign. This reduction in sensitivity may be due to the size of the population sampled, and to the more stringent inclusion/exclusion criteria that we used to select patients with a true LFPS.

When coupled with the positive predictive value (90\%), one can infer that the presence of the new sign must raise awareness in the evaluating physician as to the presence of a probable LFPS. Specificity was significantly lower than originally reported $(50 \%$ vs. $96 \%)$. This information is relevant when evaluating patients because it implies that although the presence of the sign can indicate the presence of LFPS, other tests are needed to confirm the hypothesis. Interestingly, with the inclusion/exclusion criteria used, we saw a very high rate of response after medial branch blocks, confirming not only their use as diagnostic screening tools, but as therapeutic options. ${ }^{19,20}$

The negative predictive value was markedly different from the original description (20\% vs $98 \%$ ). If this value holds true, a negative sign cannot exclude the true presence of LFPS. The overall accuracy measured was $67 \%$.

Although the new clinical sign shows promise as a new diagnostic tool, the current study shows that the evaluating clinicians must use it in conjunction with other tools to increase accurate recognition of LFPS. Nevertheless, using the inclusion/ exclusion criteria proposed here, this study could be conducted over a longer period, in order to obtain a bigger patient sample. This could provide more statistical power to determine the operating characteristics of this new sign, and its clinical significance, with greater precision.

This study also shows that appropriate selection criteria are very important when choosing which patients may benefit from a medial branch block.

\section{CONCLUSIONS}

Lumbar facet joint pain syndrome is a clinical entity of its own. There is no single way of accurately diagnosing it and like many other low-back problems, it requires the use of clinical tests conducted in parallel, to try to increase its overall sensitivity and specificity. Although our study did not achieve the same results as those obtained in the first description of the sign, this might be due to the fact that the population size was not large enough to detect differences. This would warrant the continuation of the study to improve recruitment and increase power. Nevertheless, it is clear that the non-specific innervation of the facet joints makes them almost impossible to isolate clinically through a single clinical sign. Clinicians must learn to identify patients who potentially have pain secondary to compromise of the facet joints, and to explore signs that will aid in their examination and future treatment.

All authors declare no potential conflict of interest related to this article. 


\section{REFERENCES}

1. Rubin DI. Epidemiology and Risk Factors for Spine Pain. Neurol Clin. 2007;25(2):353-71.

2. McCamey K, Evans P. Low Back Pain. Prim Care. 2007:34(1):71-82

3. Deyo RA, Weinstein JN. Low back pain. N Engl J Med. 2001;344(5):363-70.

4. Binder DS, Nampiaparampil DE. The provocative lumbar facet joint. Curr Rev Musculoskelet Med. 2009;2(1):15-24.

5. Huntoon E, Huntoon M. Differential diagnosis of low back pain. Seminars in Pain Medicine. 2004;2(3):138-44

6. Manchikanti L, Singh V. Review of chronic low back pain of facet joint origin. Pain Physician. 2002;5(1):83-101.

7. Wang J, Yang X. Age-related changes in the orientation of lumbar facet joints. Spine (Phila Pa 1976). 2009;34(17):E596-8.

8. Masharawi Y, Dar G, Peleg S, Steinberg N, Alperovitch-Najenson D, Salame K, et al. Lumbar facet anatomy changes in spondylolysis: a comparative skeletal study. Eur Spine J. 2007;16(7):993-9.

9. Tischer T, Aktas T, Milz S, Putz RV. Detailed pathological changes of human lumbar facet joints L1-L5 in elderly individuals. Eur Spine J. 2005;15(3):308-15.

10. Chaput $C$, Padon D, Rush J, Lenehan $E$, Rahm M. The significance of increased fluid signal on magnetic resonance imaging in lumbar facets in relationship to degenerative spondylolisthesis. Spine (Phila Pa 1976). 2007;32(17):1883-7.

11. Igarashi A, Kikuchi S, Konno S, Olmarker K. Inflammatory cytokines released from the facet joint tissue in degenerative lumbar spinal disorders. Spine (Phila Pa 1976). 2004;29(19):2091-5.

12. Friedrich KM, Nemec S, Peloschek P, Pinker K, Weber M, Trattnig S. The prevalence of lumbar facet joint edema in patients with low back pain. Skeletal Radiol. 2007;36(8):755-60.

13. Cohen SP, Raja SN. Pathogenesis, diagnosis, and treatment of lumbar zygapophysial (facet) joint pain. Anesthesiology. 2007;106(3):591-614.

14. Misaggi B, Gallazzi M, Colombo M, Ferraro M. Articular facets syndrome: diagnostic grading and treatment options. Eur Spine J. 2009;18(Suppl 1):49-51.
15. Manchikanti L, Pampati V, Fellows B, Bakhit CE. Prevalence of lumbar facet joint pain in chronic low back pain. Pain Physician. 1999;2(3):59-64.

16. Manchikanti L, Pampati V, Fellows B, Baha AG. The inability of the clinical picture to characterize pain from facet joints. Pain Physician. 2000;3(2):158-66.

17. Lau P, Mercer S, Govind J, Bogduk N. The surgical anatomy of lumbar medial branch neurotomy (facet denervation). Pain Med. 2004;5(3):289-98.

18. Datta S, Lee M, Falco FJ, Bryce DA, Hayek SM. Systematic assessment of diagnostic accuracy and therapeutic utility of lumbar facet joint interventions. Pain Physician. 2009;12(2):437-60.

19. Pneumaticos SG, Chatziioannou SN, Hipp JA, Moore WH, Esses SI. Low Back Pain: Prediction of Short-term Outcome of Facet Joint Injection with Bone Scintigraphy 1. Radiology. 2006;238(2):693-8.

20. Makki D, Khazim R, Zaidan AA, Ravi K, Toma T. Single photon emission computerized tomography (SPECT) scan-positive facet joints and other spinal structures in a hospital-wide population with spinal pain. Spine J. 2010;10(1):58-62.

21. Gonzalez CA. Síndrome facetario lumbar. Nuevo signo de diagnóstico clínico. Rehabilitación. 2004;38(4):168-74.

22. Masharawi Y, Rothschild B, Dar G, Pelog S, Robinson D, Been E, et al. Facet orientation in the thoracolumbar spine: three-dimensional anatomic and biomechanical analysis. Spine (Phila Pa 1976). 2004;29(16):1755-63.

23. Masharawi Y, Rothschild B, Salame K, Dar G, Peleg S, Hershkovitz I. Facet tropism and interfacet shape in the thoracolumbar vertebrae: characterization and biomechanical interpretation. Spine (Phila Pa 1976). 2005;30(11):E281-92.

24. Pal GP, Routal RV. Mechanism of change in the orientation of the articular process of the zygapophyseal joint at the thoracolumbar junction. J Anat. 1999;195(Pt 2):199-209.

25. Devereaux MW. Low back pain. Prim Care. 2004;31(1):33-51. 